ACTA AGROBOTANICA

Vol. 53, z. $2-2000$

s. $105-115$

\title{
Cropfield-weed communities of northern Poland on the eastern and western sides of the Vistula
}

\author{
KRYSTYNA SZMEJA
}

\begin{abstract}
Department of Biology and Pharmaceutical Botany, Medical University of Gdańsk,
\end{abstract} Al. Hallera 107, 80-416 Gdańsk, Poland

(Received: 3.03.2000)

\begin{abstract}
Summary
The research was carried out in the following 9 mesoregions of northern Poland, located on either side of the Vistula: Cassubian Coast, Cassubian Lakeland, Elblang Plateaux, Górowo Plateaux, Ermelandic Plain, Iława Lakeland, Vistula Delta, Starogard Lakeland and Lower Vistula Valley. A total of 11 cropfield-weed communities have been distinguished and described. Those found in cereal crops included: Teesdaleo-Arnoseridetum, Papaveretum argemones, a transition community between Vicietum tetraspermae and Aphano-Matricarietum, AphanoMatricarietum, Lathyro-Melandrietum and Spergulo-Chrysanthemetum segeti. In root crops the occurrence was found of: Digitarietum ischaemii, EchinochlooSetarietum, Lamio-Veronicetum politae, Galinsogo-Setarietum, Fumarietum officinalis and Spergulo-Chrysanthemetum segeti. Due to the presence in the patches of most communities, especially root crop communities, of many common species, they show a number of similarities, floristic and structural.
\end{abstract}

Key words: weed communities, phytosociology, northern Poland.

\section{INTRODUCTION}

Weed communities are a sensitive indicator of habitats and cultivating practices applied, e.g. herbicide treatment, reclamation (W ó j c i k, K m o s e k, 1988). Many anthropogenic actions eliminate some weed species, especially stenotopic ones, 
that is with a narrow ecological scale. The weed elimination process appeared to have been fairly common, especially during the last two and a half decades (K o r n a ś, 1970, 1971; M i r e k, 1976; S z m e j a, 1986). Many weed communities thus partially changed their original structure.

Because of the political-system changes in Poland, in the last decade of the $20^{\text {th }}$ century changes in the structure of agriculture were started. In many regions, large-area state-owned farms were gradually replaced by small privately-held farms. This process will have a significant effect on the distribution and structure of cropfield weed communities mainly in north-western Poland. Tracing these changes must be preceded by exact recording of the segetal vegetation on spatial micro- and macroscales. In many regions of this part of Poland cropfield vegetation has become the subject of appropriate detailed studies (H e r b i c h, 1982; S z m e j a, 1986, 1987, 1989, 1994; H o ł d y ń s k i, 1991), but so for there have been few synthetical studies (M a t u s z k i e w i c z, 1982; W ó j c i k, 1973). Contemporary trends of changes in the segetal vegetation of this area are still rather little understood.

The aim of the present study is to provide a synthesis of the information concerning the type of segetal vegetation in the selected part of northern Poland, situated on either side of the Vistula. The synthesis concerns the kind of cropfield weed communities found in the following nine regions: Cassubian Coast, Cassubian Lakeland, Elblag Plateaux, Górowo Plateaux, Ermelandic Plain, Iława Lakeland, Vistula Delta, Starogard Lakeland and Lower Vistula Valley. The total surface area is $14682 \mathrm{~km}^{2}$, including the eastern part of the Pomeranian Lakeland and a small fragment of the Eastern - Pomeranian Lakeland (Ko n d r a c k i, 1980).

\section{MATERIAL AND METHODS}

In the study 540 phytosociological records have been used. The records were made in the years 1973-1999, by the Braun-Blanquet method (P a w lo w s k i, 1972), during the period of optimum growth of cereal- (June, July) and root- (September, October) crop weeds. Only species of the $2^{\text {nd }}$, at least, degree of constancy were taken into account in the analysis of weed communities. The material to be studied was divided into two groups: weeds derived from regions west of the Vistula (Cassubian Lakeland, Cassubian Coast, Starogard Lakeland, Lower Vistula Valley and Vistula Delta), and from regions east of the Vistula (Elblag Plateaux, Górowo Plateux, Ermelandic Plain, Iława Lakeland and the eastern part of the Vistula Delta) (Fig. 1).

In the table communities are arranged according to increasing soil fertility, from dry and sandy habitats poor in nutrients, to moist clayey ones, rich and characterized by a considerable biological activity.

Plant names have been adopted according to M i r e k et al., (1995). 


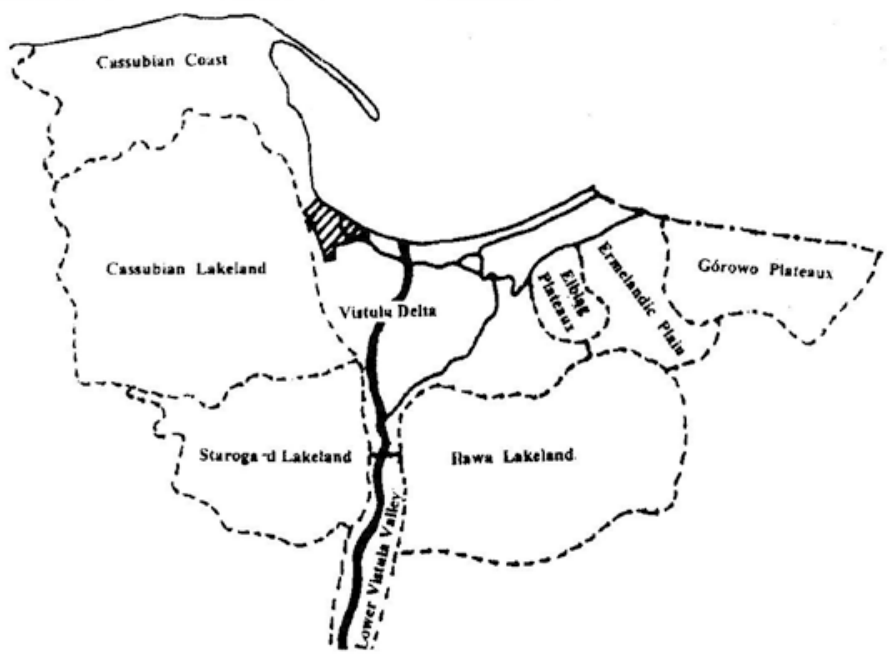

Fig. 1. Distribution of the physico-geographical units under study

\section{RESULTS AND CONCLUSIONS}

In nine regional units, east and west of the Vistula, 11 cropfield weed communities have been found. They included: Teesdaleo-Arnoseridetum, Papaveretum argemones, a transition community between Vicietum tetraspermae and Aphano-Matricarietum, Aphano-Matricarietum, Spergulo-Chrysanthemetum segeti, Lathyro-Melandrietum, Digitarietum ischaemii, Echinochloo-Setarietum, Galinsogo-Setarietum, Lamio-Veronicetum politae and Fumarietum officinale.

The above communities are made up of a large number of common species (Table 1), characterized by a wide scale of ecological requirements, including phytocoenotic ones. This species group includes Viola arvensis, Chenopodium album, Agropyron repens, Fallopia convolvulus and Myosotis arvensis. Other weeds, e.g. Cirsium arvense, Equisetum arvense, Matricaria maritima subsp. inodora, Polygonum aviculare, Capsella bursa-pastoris, Stellaria media, Polygonum lapathifolium subsp. pallidum, Centaurea cyanus, Vicia hirsuta, Thlaspi arvense and Sinapis arvensis are only occurring in some of the communities found east and west of the Vistula.

The communities distinguished differ among other things by the type of habitats they occupy. On poor, sandy and dry soils Teesdaleo-Arnoseridetum occurs which in root-crop fields is replaced by Digitarietum ischaemii. In TeesdaleoArnoseridetum the main species are first of all Teesdalea nudicaulis, Arnoseris minima, Agrostis giganthea and Anthoxanthum aristatum. West of the Vistula the latter species is an expansive weed that colonizes mainly rye fields on light soils. A similar distribution is found for Digitarietum ischaemii which also occupies light soils, but is very rarely represented. Digitaria ischaemum and Setaria viridis give a specific physiognomy to patches of this community; in the study area the former is far less frequent than the latter. 
Another group of communities includes Papaveretum argemones and Echinochloo-Setarietum. Both communities are found on soils that are warm, well aerated and at the same time richer in nutrients than soils from which TeesdaleoArnoseridetum and Digitarietum ischaemii have been recorded. Papaveretum argemones patches form on both sides of the Vistula, except that west of the river Papaver rhoeas, Vicia villosa, Lithospermum arvense and Trifolium arvense are more frequent. In addition, Papaver argemone is more frequent west (constancy class V) than east (constancy class II) of the Vistula, while Papaver dubium - reversely (class III versus IV). West of the Vistula, in patches of this community more frequent are acidophilous species, e.g. Rumex acetosa, Spergula arvensis, Scleranthus annuus and Raphanus raphanistrum. A common feature of this community on both sides of the Vistula is a fairly frequent (constancy class II) occurrence of Aphanes arvensis the characteristic species of Aphano-Matricarietum.

In the same habitats in which Papaveretum argemones occurs in grain crops Echinochloo-Setarietum develops in root crops. Typically formed patches of this association are only found in areas west of the Vistula. Constantly present in them is Echinochloa crus-galli accompanied by Setaria viridis, Amaranthus retroflexus and Geranium pusillum. In areas east of the Vistula this association nearly always includes Galinsoga ciliata and G. parviflora. Due to this floristic composition it becomes similar to Galinsogo-Setarietum.

A further group of communities is Aphano-Matricarietum and a transition community between Aphano-Matricarietum and Vicietum tetraspermae. A common feature of these two units of segetal vegetation is the constant presence in them of Aphanes arvensis. East of the Vistula Chamomilla recutita is usually absent from Aphano-Matricarietum, because it occurs there mainly in ruderal habitats. Also, in patches of this association west of the Vistula the following species are less frequent: Ranunculus repens, Juncus bufonius, Gnaphalium uliginosum, Polygonum lapathifolium subsp. pallidum and Plantago intermedia. They are more frequently recorded for areas east of the Vistula, where they are indicators of a good moisture of the soil and arable layer. Aphano-Matricarietum patches on either side of the Vistula are linked by a sizeable group of common species, e.g. Veronica arvensis, Polygonum persicaria, Apera spica-venti, Poa annua, Achillea millefolium, Raphanus raphanistrum and Vicia angustifolia which were not encountered in patches of the transition community between Vicietum tetraspermae and Aphano-Matricarietum.

Spergulo-Chrysanthemetum segeti occupies habitats similar to those occupied by Aphano-Matricarietum. A specific characteristic of Spergulo-Chrysanthemetum segeti is the constant presence of Polygonum lapathifolium subsp. lapathifolium and Chrysanthemum segetum; the latter has infested many cropfields and is difficult to control. West of the Vistula Spergulo-Chrysanthemetum segeti rarely includes species of the alliance Eu-Polygono-Chenopodion, e.g. Lamium amplexicaule, L. purpureum, and Sonchus asper, and absent from it are plants with high tropic requirements, e.g. Erysimum cheiranthoides, Sinapis arvensis, Thlaspi arvense, Sonchus arvensis, Vicia hirsuta and Centaurea cyanus. Present, however, are plants like Artemisia vulgaris, Erodium cicutarium, Rumex acetosella, Anchusa officinalis and Galeopsis tetrahit which are much rarer than in regions east of the Vistula. 
Lathyro-Melandrietum - a further cropfield weed community - in the study area its occurrence is restricted to the Lower Vistula Valley where it develops on very rich black soils. In addition to the characteristic species, i.e. Lathyrus tuberosus and Melandrium noctiflorum, there occurred many calciphilous plants of the alliance Caucalidion daucoidis, e.g. Adonis aestivalis, Euphorbia exigua, Ranunculus arvensis and Fumaria vaillantii. In patches of this association the characteristic species of Aphano-Matricarietum, Vicietum tetraspermae and Papaveretum argemone do not occur, and the Aperion spicae-venti alliance is poorly represented. Because of such a species composition, Lathyro-Melandrietum cannot be classified among the richsoil forms of one of the above-listed plant communities.

In the area under study the richest soils are occupied by Galinsogo-Setarietum, Lamio-Veronicetum politae and Fumarietum officinale. Galinsogo-Setarietum patches form on intensively fertilized soils, especially on manured soils, and in fields near farmsteads. Frequent components of this association are Galinsoga parviflora and Galinsoga ciliata, usually accompanied by Solanum nigrum and Veronica polita. In patches of this association found east of the Vistula Echinochloa crus-galli occurs constantly.

Lamio-Veronicetum politae is characterized by a constant presence of Veronica agrestis and Veronica polita. East of the Vistula patches of this association are floristically richer, among other things because of the more frequent occurrence of species of the Eu-Polygono-Chenopodion alliance, especially Lamium purpureum, Sonchus asper and Veronica persica, and also on account of the presence of more fertile soils.

Fumarietum officinale is often formed near Lamio-Veronicetum politae patches. In segetal plant syntaxonomy these two communities are fairly close and are for this reason sometimes erroneously identified. The main characteristic species of Fumarietum officinalis is Fumaria officinalis whose constancy is very high (Table 1). Typically formed patches of this association were found west of the Vistula where they were accompanied by other species of the Eu-Polygono-Chenopodion alliance, e.g. Lamium amplexicaule, L. purpureum and Sonchus asper. East of the Vistula Fumarietum officinale occurs in a floristically poorer form, because a number of species of the Eu-Polygono-Chenopodion alliance are missing, while Fumaria officinalis is less frequent than, e.g. in the Cassubian Lakeland.

The following conclusions were drawn from the study:

1. In nine regional units, located in northern Poland on either side of the Vistula, 11 cropfield weed communities have been found. In grain fields the following have been recorded: Teesdaleo-Arnoseridetum, Papaveretum argemones, a transition community between Vicietum tetraspermae and AphanoMatricarietum, Lathyro-Melandrietum and Spergulo-Chrysanthemetum segeti. In root-crop fields: Digitarietum ischaemii, Echinochloo-Setarietum, LamioVeronicetum politae, Galinsogo-Setarietum, Fumarietum officinalis and Spergulo-Chrysanthemetum segeti. 
2. Lamio-Veronicetum politae, Galinsogo-Setarietum, Fumarietum officinalis and Spergulo-Chrysanthemetum segeti have a number of species in common, especially species of the alliance Eu-Polygono-Chenopodion. Because of their presence, patches of these association are floristically similar.

3. Digitarietum ischaemii is an association commonly occurring west of the Vistula. Its patches are often found there, its characteristic species being abundant. East of the Vistula, where rich and moist habitats are more frequent, phytocoenoses of this association are less abundant.

4. Aphano-Matricarietum is well developed in terrains east of the Vistula, but in areas west of this river in northern Poland, its patches are floristically poorer and often similar to Papaveretum argemones.

5. Spergulo-Chrysanthemetum segeti occurs in grain- and root-crop fields.

6. Lathyro-Melandrietum was only found in regions west of the Vistula, on very fertile soils in the Lower Vistula Valley. This association is distinguishable by the presence of many species of the Caucalidion daucoidis alliance. These species have not been found in any other cropfield weed community.

\section{REFERENCES}

H e r b i c h J.,1982. Zróżnicowanie i antropogeniczne przemiany roślinności Wysoczyzny Staniszewskiej na Pojezierzu Kaszubskim (Differentiation and anthropogenic transformation of vegetation in the Staniszewo Upland in the Cassubian Lakeland). Monogr. Bot. 63: 1-162.

H oł d y ń s k i Cz., 1991. Flora segetalna, zróżnicowanie florystyczno-ekologiczne i przemiany szaty roślinnej pól uprawnych w aktualnych warunkach agroekologicznych Żuław Wiślanych - (Segetal flora, floristic and ecologic differentiation and changes in the plant - cover of cultivated fields in current agroecologic conditions of Vistula Delta). Acta Acad. Agricult. Tech. Olst., Agricultura 51, Supp. B: 3-50.

K o n d r a c k i J., 1980. Geografia fizyczna Polski (Physical geography of Poland) - PWN, Warszawa, pp. 463.

K o r n a ś J., 1970. Współczesne zmiany flory polskiej (Present changes of Polish flora). Wszechświat 9: 229-234.

K o r n a ś J., 1971. Uwagi o współczesnym wymieraniu niektórych gatunków roślin synantropijnych w Polsce (Recent decline of some synanthropic plant species in Poland). Mater. Zakł. Fitosoc. Stos. UW 27: 51-64.

M a t u s z k i e w i c z W., 1982. Przewodnik do oznaczania zbiorowisk roślinnych Polski (A guide to the plant communities of Poland) - PWN, Warszawa, pp.310.

Mire k Z., P ię koś-M irkow a H., Z a ją c A., Z a ja c M., 1995. Krytyczna lista roślin naczyniowych Polski (Vascular plants of Poland a checklist) - Polish Botanical Studies, Guidebook series 15 .

M i r e k Z., 1976. Zanikanie chwastu lnowego Camelina alyssum (Mill.) Thell. na terenie Polski (The exctinction of flax weed Camelina alyssum (Mill.) Thell. in Poland.) Phytocoenosis 5. 3-4:227-236.

P a w ł o w s k i B., 1972. Skład i budowa zbiorowisk roślinnych oraz metody ich badania (Composition and structure of plant communities and methods for studying them). [In: Szata roślinna Polski (Plant cover of Poland) (Ed. W. Szafer, K. Zarzycki)] - PWN, Warszawa, 2: 269-278. 
S z m e j a K.,1986. Spergulo-Chrysanthemetum segeti (Br.- BL. et De Leeuw 1936) R.Tx. 1937 w uprawach zbóż jarych i okopowych Wzniesień Elbląskich, Równiny Warmińskiej i Wzniesień Górowskich (The Spergulo-Chrysanthemetum segeti (Br.- BL. et De Leeuw 1936) R.Tx. 1937 in spring grain and root crops on the Elblag Plateaux, Ermelandic Plain and Górowo Plateaux). Fragm. Flor. et Geobot., 29 (3-4): 385-392.,

S z m e j a K.,1987. Lathyro-Melandrietum Oberd.1957 na czarnych ziemiach gniewskich w Dolinie Dolnej Wisły (The Lathyro-Melandrietum Oberd. 1957 on the black soils of Gniew in the Lower Vistula Valley). Zesz. Naukowe Akademii Rolniczej im. H. Kołłataja w Krakowie, 26 (9): 37-48.

S z m e j a K.,1989. Roślinność pól uprawnych Wzniesień Elbląskich (The vegetation of the crop field cultivations on the Elblag Plateaux). Sc. Sc. Gedan., Acta Biologica 7, GTN, Wydz. II Nauk Medycznych i Biologicznych, PAN, Wrocław-Warszawa- Kraków-GdańskŁódż, 65 ss.

Szmeja K., 1994. Roślinność pól uprawnych Zaborskiego Parku Krajobrazowego (Farmland vegetation of the Zaborski Landscape Park). Fragm. Flor. Geobot. Ser. Polonica 1:57-80.

W ó j c i k Z., 1973. The plant communities of root-crop fields in lowlands and higlands of Poland. Floristic, ecologic and regional differentiation. Feddes Repert. Beih. 84:573-588.

W ó j c i k Z., K m o s e k S., 1988. Spatial differentiation of segetal communities of Lomianki commune and their changes over the last quarter of century. Pol. Ecol. Stud. $14(1-2): 123-143$.

\section{Zbiorowiska chwastów upraw polnych Polski północnej po wschodniej i zachodniej stronie Wisły}

\section{Streszczenie}

Badania roślinności segetalnej prowadzono w dziewięciu mezoregionach Polski północnej, położonych po obu stronach Wisły. Sa to: Pobrzeże Kaszubskie, Pojezierze Kaszubskie, Wzniesienia Elbląskie, Wzniesienia Górowskie, Równina Warmińska, Pojezierze Iławskie, Żuławy Wiślane, Pojezierze Starogardzkie i Dolina Dolnej Wisły. W pracy wyróżniono i opisano 11 zbiorowisk chwastów upraw polnych. W uprawach zbożowych są to: Teesdaleo-Arnoseridetum, Papaveretum argemones, zbiorowisko przejściowe między Vicietum tetraspermae i Aphano-Matricarietum, Lathyro-Melandrietum i Spergulo-Chrysanthemetum segeti. W uprawach okopowych stwierdzono występowanie: Digitarietum ischaemii, Echinochloo-Setarietum, LamioVeronicetum politae, Galinsogo-Setarietum, Fumarietum officinalis i SperguloChrysanthemetum segeti. Występowanie w płatach większości zbiorowisk, zwłaszcza okopowych, wielu gatunków wspólnych sprawia, że wykazują one szereg podobieństw zarówno florystycznych jak i strukturalnych. 
Table 1. Floristic comparision of weed communities of field cultivations of the eastern and western sides of the Vistula

\section{Species}

Arnoseris minima

Teesdalea nudicaulis

Anthoxanthum aristatum

Agrostis giganthea

Setaria viridis

Digitaria ischaemum

Myosotis stricta

Trifolium arvense

Arabidopsis thaliana

Papaver rhoeas

Vicia villosa

Lithospermum arvense

Papaver argemone

Papaver dubium

Veronica hederifolia

Raphanus raphanistrum

Geranium pusillum

Amaranthus retroflexus

Echinochloa crus-galli

Stachys palustris

Galinsoga ciliata

G. parviflora

Solanum nigrum

Vicia tetrasperma

Anagallis arvensis

Galeopsis bifida

Melandrium album

Chamomilla recutita

Aphanes arvensis

Ranunculus repens

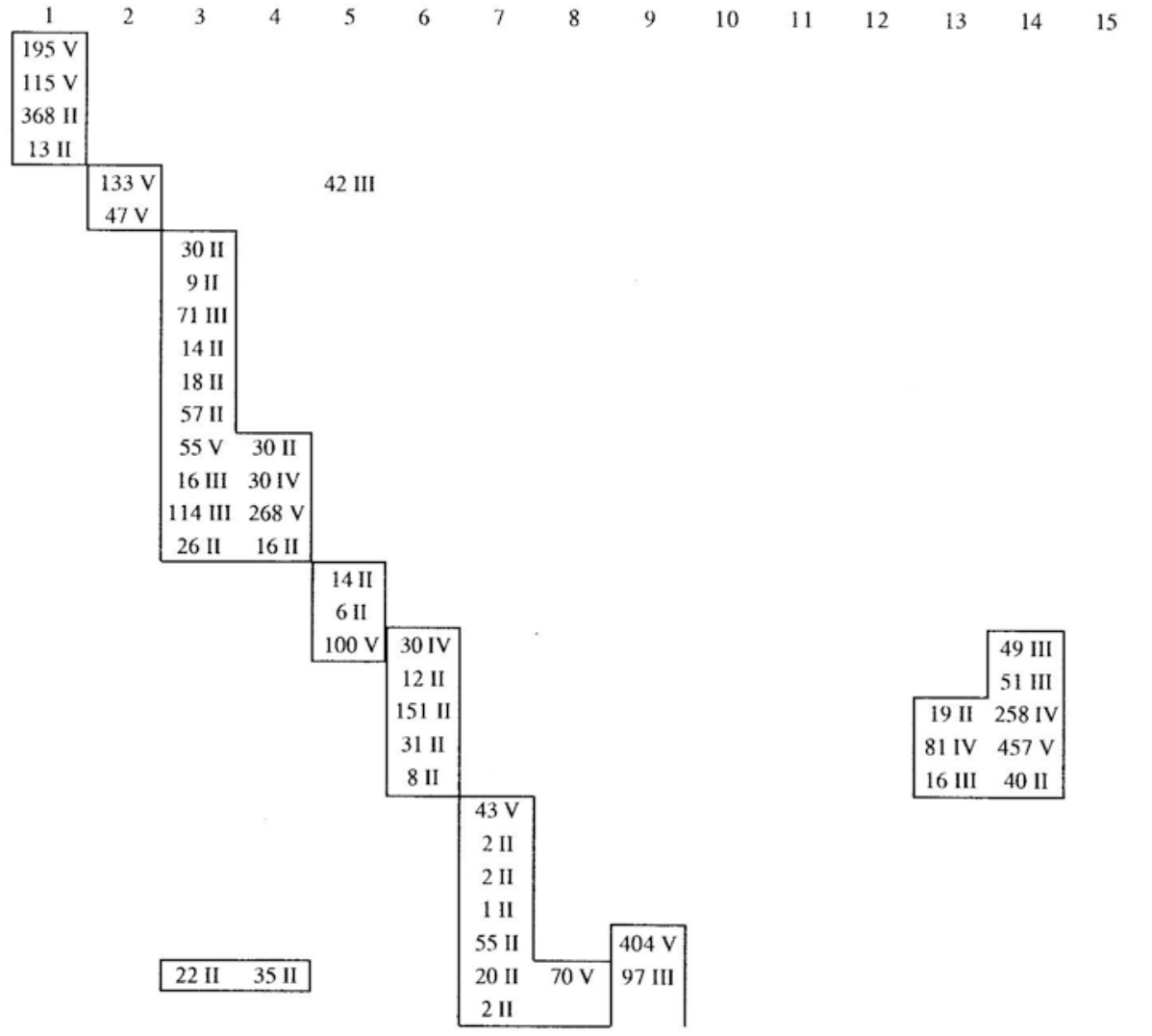

16 
Juncus bufonius

Gnaphalium uliginosum

Polygonum lapathifolium ssp.

brittingeri

Plantago intermedia

Vicia sativa

Chrysanthemum segetum

Crepis tectorum

Polygonum hydropiper

Polygonum lapathifolium

ssp. lapathifolium

Lathyrus tuberosus

Adonis aestivalis

Euphorbia exiguo

Consolida regalis

Papaver rhoeas

Aethusa cynapium

Fumaria vaillantii

Ranunculus arvensis

Descurainia sophia

Atriplex patula

Melandrium noctiflorum

Galium spurium

Veronica agrestis

Lapsana communis

Euphorbia helioscopia

Veronica polita

Sonchus oleraceus

Anagallis arvensis

Sinapis alba

Fumaria officinalis

Medicago lupulina

Arenaria serpyllifolia

Lamium amplexicaule
60 II

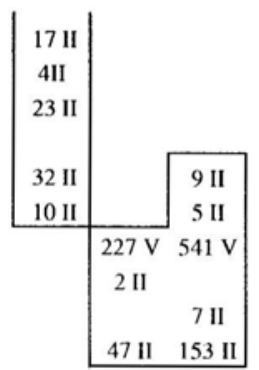

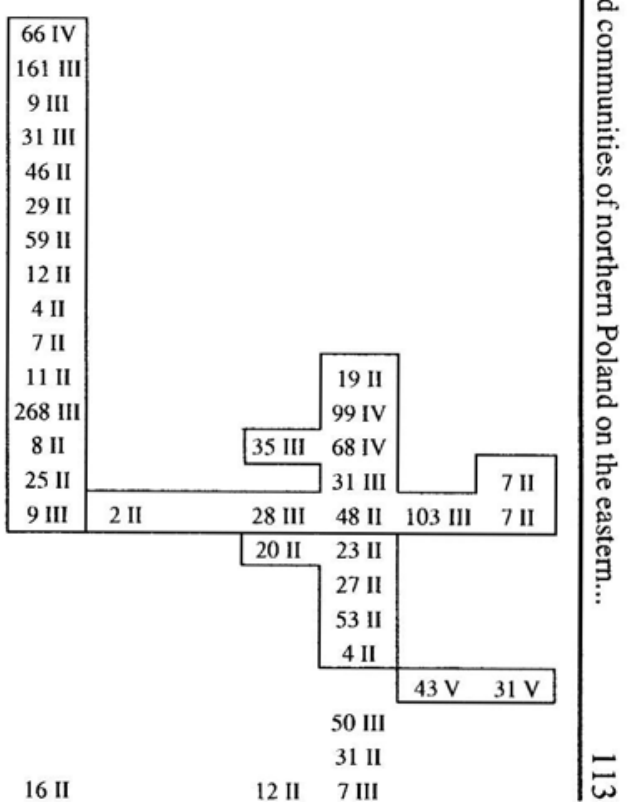


Trifolium repens

Lamium purpureum

Galeopsis speciosa

Sonchus asper

Erodium cicutarium

Rumex acetosella

Erysimum cheiranthoides

Carduus crispus

Veronica arvensis

Polygonum persicaria

Apera spica- venti

Poa annua

Achillea millefolium

Raphanus raphanistrum

Anthemis arvensis

Vicia angustifolia

Polygonum amphibium

Scleranthus annuus

Veronica persica

Avena fatua

Artemisia vulgaris

Anchusa arvensis

Galeopsis tetrahit

Spergula arvensis

Taraxacum officinale

Mentha arvensis

Sinapis arvensis

Thlaspi arvense

Sonchus arvensis

Vicia hirsuta

Centaurea cyanus

Polygonum lapathifolium ssp.pallidum 45 II 92 II

Stellaria media

Capsella bursa-pastoris

$12 \mathrm{II}$
$98 \mathrm{III}$

24 III

$48 \mathrm{II}$

$20 \mathrm{III}$

13 II

$310 \mathrm{IV}$

79 IV 57 II

73 II

$\begin{array}{lllll}15 \mathrm{II} & 5 \mathrm{II} & 4 \mathrm{II} & 12 \mathrm{III} \\ 77 \mathrm{HII} & 3 \mathrm{II} & & & \end{array}$

$38 \mathrm{II}$

$2 \mathrm{II} \quad 16 \mathrm{II}$

109 IV 23 II 27 II

$8 \mathrm{II}$

$11 \mathrm{II} \quad 30 \mathrm{II}$

14 II

392 IV 49 II

$13 \mathrm{II} \quad 4 \mathrm{II} \quad 4 \mathrm{II}$

93 II

4 II 24 III

27 II

$$
88 \mathrm{HII}
$$

42 III

$40 \mathrm{III}$

$\begin{array}{ccccccc} & & & & & \\ & & & 37 \mathrm{III} & 6 \mathrm{II} & \\ & & & & 12 \mathrm{II} & \\ & & & 28 \mathrm{III} & & 8 \mathrm{II} \\ & & & 50 \mathrm{II} & \\ 4 \mathrm{II} & 20 \mathrm{III} & 10 \mathrm{II} & & 25 \mathrm{II} & 38 \mathrm{II} \\ & & & 27 \mathrm{II} & 12 \mathrm{II} & 7 \mathrm{II} \\ & & & 31 \mathrm{II} & & 12 \mathrm{II} \\ & 25 \mathrm{II} & & & & 7 \mathrm{II}\end{array}$

$38 \mathrm{II} \quad 31 \mathrm{III} \quad 51 \mathrm{~V} \quad 32 \mathrm{III}$

$218 \mathrm{~V} \quad 185$ III 122 IV

151 II 13 III 26 II

$14 \mathrm{II} 9 \mathrm{II} \quad 20 \mathrm{III} \quad 3 \mathrm{II}$

$21 \mathrm{II} \quad 22 \mathrm{II} \quad 97 \mathrm{IV} \quad 9 \mathrm{II}$

$83 \mathrm{III} \quad 7 \mathrm{II}$

22 III $8 \mathrm{III} \quad 12 \mathrm{II}$

$16 \mathrm{III} \quad 10 \mathrm{II}$

9 II

9 II $\quad 11 \mathrm{II} \quad 21 \mathrm{II} \quad 9$ II

$29 \mathrm{III} \quad 186 \mathrm{III} \quad 87 \mathrm{II} \quad 30 \mathrm{HII} \quad 27 \mathrm{HII}$

46 II

32 II $46 \mathrm{II} \quad 1 \mathrm{II}$

84 III $\quad 36$ II $\quad 7$ II $\quad 41$ III

6 II

36 II 7 II 41 III 13 II

62 III $\quad 2$ II $\quad 74$ III

$\begin{array}{llllrr}3 \text { II } & 18 \text { II } & 7 \text { II } & & 3 \text { II } & 3 \text { II }\end{array}$

14 II 4 II

29 III 17 III 112 V 69 IV

$\begin{array}{llllllll}23 \mathrm{II} & 23 \mathrm{II} & 66 \mathrm{~V} & 125 \mathrm{IV}\end{array}$

25 II

$4 \mathrm{II} \quad 3 \mathrm{II}$

5 II 3 III

49 III 27 II $\quad 6$ III 24 III

43 II 48 III 12 III

2 II

80 III $\quad 72$ III 25 II $\quad 18$ II 12 III 80 III 59 IV

145 IV 68 III 8. II $\quad 12$ III 120 IV 225 IV

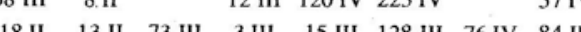

24 II $190 \mathrm{~V} \quad 63$ III 143 IV 67 IV $200 \mathrm{~V} 263 \mathrm{~V}$

$\begin{array}{lllllllll}27 \mathrm{II} & 49 \mathrm{III} & 74 \mathrm{III} & 53 \mathrm{IV} & 2 \mathrm{II} & 15 \mathrm{II} & 13 \mathrm{III} & 17 \mathrm{III} & 17 \mathrm{III}\end{array}$
95 II

$8 \mathrm{II} \quad 83 \mathrm{IV}$

22 II 40 III 19

8 III

39 IV

57 IV

84 III

$296 \mathrm{~V}$
31 II

43 II 89 III

$$
8 \text { III } 3 \text { II } 25 \text { II }
$$

51 II

$$
4 \text { II } 3 \text { II }
$$

$30 \mathrm{II}$$$
84 \text { II }
$$

30 II

13 II

7 III $\quad 8$ II 46 II 93 IV 35 II 13 II

12 II 31 III 84 III 39 III

35 II 4 II 11 III 13 II 3 II

8 II 23 II 22 II 33 II 13 II

30 II $\quad 8$ II 29 II 32 IV

$8 \mathrm{II} \quad 27 \mathrm{II} \quad 20 \mathrm{II}$

19 III 7 III 36 IV 5 II

$100 \mathrm{II} 72 \mathrm{II} \quad 46 \mathrm{II} 61 \mathrm{II}$

$30 \mathrm{IV} \quad 4 \mathrm{II} \quad 38 \mathrm{III} \quad 20 \mathrm{II} \quad 149 \mathrm{IV} \quad 109 \mathrm{IV}$

$32 \mathrm{IV} \quad 49 \mathrm{III} \quad 30 \mathrm{III} \quad 11 \mathrm{II}$

97 IV $128 \mathrm{~V} \quad 53$ III 54 IV 114 III $96 \mathrm{~V}$

8 II $\quad 9$ III 53 III 5 II $\quad 4$ II

32 II 69 III $\quad 18$ II 74 III 15 III

159 III $\quad 23$ III 6 II 11 III 36 III

$74 \mathrm{~V} \quad 173 \mathrm{IV} 206 \mathrm{~V} 257 \mathrm{~V} \quad 181 \mathrm{IV} 205 \mathrm{IV}$

24 III 36 III 52 III 41 II 23 II 22 II
29 II 26 III 8 II 
Polygonum aviculare

Matricaria maritima ssp. inodora

Equisetum arvense

Cirsium arvense

Myosotis arvensis

Fallopia convolvulus

Agropyron repens

Chenopodium album

Viola arvensis $\begin{array}{lllllllllllllllll}30 & \mathrm{II} & 37 \mathrm{III} & 20 \mathrm{III} & 55 \mathrm{III} & 2 \mathrm{IV} & 53 \mathrm{IV} & 36 \mathrm{IV} & 33 \mathrm{II} & 17 \mathrm{III} & 68 \mathrm{III} & 32 \mathrm{II} & 8 \mathrm{II} & 28 \mathrm{III} & 38 \mathrm{III} & 11 \mathrm{III} & 14 \mathrm{III}\end{array}$

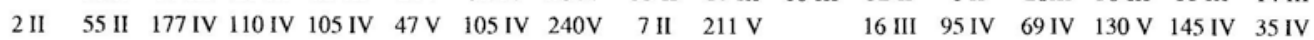

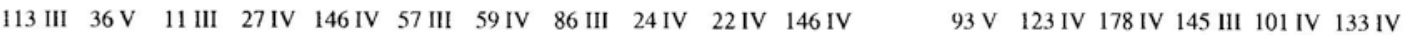
$\begin{array}{llllllllllllllllll}90 \mathrm{IV} & 65 \mathrm{II} & 35 \mathrm{IV} & 67 \mathrm{III} & 44 \mathrm{IV} & 25 \mathrm{IV} & 82 \mathrm{IV} & 49 \mathrm{IV} & 17 \mathrm{III} & 17 \mathrm{III} & 22 \mathrm{III} & 86 \mathrm{~V} & 14 \mathrm{III} & 131 \mathrm{IV} & 72 \mathrm{IV} & 72 \mathrm{IV} & 156 \mathrm{~V}\end{array}$

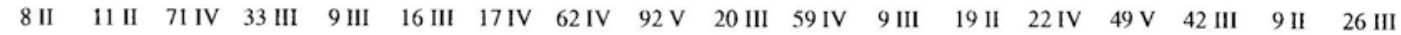

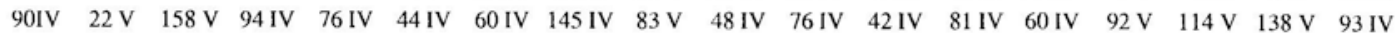

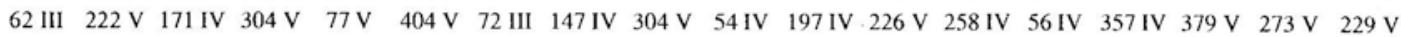
43 III 35 IV 62 IV 250 III $233 \mathrm{~V} \quad 555 \mathrm{~V} \quad 47$ IV 87 III $116 \mathrm{~V} \quad 27$ IV 123 IV 127 IV $258 \mathrm{~V} \quad 257 \mathrm{~V} 264 \mathrm{~V} \quad 457 \mathrm{~V} \quad 370 \mathrm{~V} \quad 249 \mathrm{~V}$

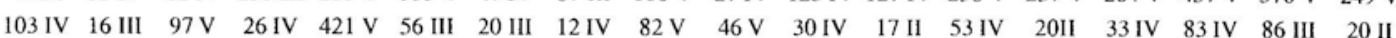

\section{Explanations:}

1 -Teesdaleo-Arnoseridetum (PZ),

2 - Digitarietum ischaemi (PZ),

3 - Papaveretum argemones (PZ),

4 - Papaveretum argemones (PW),

5 - Echinochloo-Setarietum (PZ),

6 - Echinochloo-Setarietum (PW),

7 - a transition community between Vicietum tetraspermae and Aphano-Matricarietum (PZ),

8 - Aphano-Matricarietum (PZ),

9 - Aphano-Matricarietum (PW),

10 - Spergulo-Chrysanthemetum segeti (PZ),

11 - Spergulo-Chrysanthemetum segeti (PW),

12 - Lathyro-Melandrietum (PZ),

13 - Galinsogo-Setarietum (PZ),

14 - Galinsogo-Setarietum (PW),

15 - Lamio-Veronicetum politae (PZ),

16 - Lamio-Veronicetum politae (PW),

17 - Fumarietum officinale (PZ),

18 - Fumarietum officinale (PW).

PZ - regions of the west of Vistula

PW - regions of the east of Vistula 